\title{
The Effect of Quality Extension and Education on Clean and Healthy Behavior (PHBS) through Community Understanding in the Work Area of Public Health Centre
}

\author{
Ahral, Gunawan Bata Ilyas and Trimaya Cahya Mulat \\ Sekolah Tinggi Ilmu Ekonomi AMKOP Makassar, Indonesia \\ ahral@gmail.com,gunawan@stieamkop.ac.id,trimayacm11@gmail.com \\ Tehubijuluw Zacharias \\ Universitas Kristen Indonesia, Maluku, Indonesia \\ tehubijuluwzacharias@yahoo.com \\ Yusriadi Yusriadi \\ Sekolah Tinggi Ilmu Administrasi Puangrimaggalatung, Makassar, Indonesia \\ yusriadi.yusriadi@uqconnect.edu.au \\ Firman Gazali Djunaidi \\ Universitas Iqra Buru \\ firmangazalidjunaidi@gmail.com \\ Nurman Achmad \\ Universitas Sumatera Utara \\ nurman@usu.ac.id
}

\begin{abstract}
This research used an approach with a quantitative approach. The sample used was 107 patients at the Public Health Center, Bulukumba Regency. The research instrument used to obtain data is a questionnaire data analysis techniques to test hypotheses using path analysis with the SPSS for Windows program's help. The results of this study indicate that: (1) The quality of extension agents has a positive and significant direct effect on people's understanding of PHBS. (2) Education has a positive and significant immediate impact on people's knowledge of PHBS. (3) The quality of extension agents has a positive and significant direct effect on increasing PHBS. (4) Education has a positive and significant immediate impact on improving PHBS. (5) Public understanding has a positive and significant direct effect on increasing PHBS. (6) The quality of extension agents has an indirect positive but insignificant impact on improving PHBS through community understanding. (7) Education has a positive and significant indirect effect on improving PHBS through public awareness.
\end{abstract}

Keywords:

Quality of Extension, Education, Community Understanding, Clean and Healthy Living Behavior

\section{Biographies}

Ahral is a student at Magister Program of Economic Science of STIE AMKOP, Indonesia. His areas of interest and research include social science and economic. He has published some articles in national journals.

Gunawan Bata Ilyas is is a lecturer at Magister Program of Economic Science of STIE AMKOP, Indonesia. He has done many research pieces in studying Human Resources, Human Development Theory, and Environmental 
Economics. As a researcher, he has published many articles in both national and international journals, and also some books. He is also a reviewer and editor in several accredited journals.

Trimaya Cahya Mulat is a lecturer at Economics Department of STIE AMKOP, Indonesia. Her areas of interest and research include economic, management, management human resource. She has published some books and many articles in national and international journals.

Tehubijuluw Zacharias is is a lecturer at Public Administration Department of Universitas Kristen Indonesia, Maluku, Indonesia. His areas of interest and research include social science, political science, sociology, legal studies, and public administration. He has published some books and many articles in national and international journals.

Yusriadi Yusriadi is a lecturer at Public Administration Department of Sekolah Tinggi Ilmu Administrasi Puangrimaggalatung, Indonesia and chancellor on Sekolah Tinggi Ilmu Hukum Pengayoman. His areas of interest and research include social science, political science, sociology, legal studies, and public administration. He has published some books and many articles in national and international journals. He is a reviewer and editor in some local and international journals.

Firman Gazali Djunaidi, He is a lecturer at Iqra Buru University and currently serves as the dean of the Faculty of Economics. He is an alumnus of the Ambon Pattimura University with a management science specification. Currently, he is incessantly publishing articles in national and international journals, he also encourages Small and Medium Enterprises in Buru Regency to go forward, and he is also the recipient of the DIKTI 2020 grant, and now he has also passed a research grant, and it is proven that he is an active lecturer and can process local materials hurried into a product, namely he created a bath soap based on eucalyptus oil.

Nurman Achmad is a lecturer at the University of North Sumatra. currently still active in the process of teaching and researching. 